\title{
Miospores, correlation and age of some Scottish Lower Old Red Sandstone sediments from the Strathmore region (Fife and Angus)
}

\author{
JOHN B. RICHARDSON ${ }^{1}$. JANCIS H. FORD ${ }^{2}$ \& FRANCES PARKER ${ }^{3}$ \\ ${ }^{1}$ British Museum (Natural History), Cromwell Road, London SW7 5BD \\ ${ }^{2}$ Nova Husky Research Corp., 1411-25 Avenue N.E., Calgary, Alberta, Canada T2E 7L6 \\ ${ }^{3}$ University of Western Australia, Nedlands, Western Australia 6009
}

\begin{abstract}
The age of some Lower Old Red Sandstone sediments (Arbuthnott Group) is reassessed and confirmed as Lower Devonian (lower Gedinnian) on the basis of a reinvestigation of spore assemblages. The data upon which this age assessment is based are provided by recent palynological researches in the Welsh Borderland, the type area of the Gedinnian (Belgium), and the graptolite-bearing parastratotype for the Silurian-Devonian boundary (Podolia). Samples from the Arbuthnott Group at Wormit (Fife), associated with rocks dated as $407 \pm 6 \mathrm{Ma}$ by Thirlwall (1983) and regarded by him as Silurian, have yielded miospore assemblages of early but not earliest Devonian when compared with the Podolian SilurianDevonian sequence. Samples throughout the sequence of the Arbuthnott Group as exposed in Angus and Fife have yielded miospores. These assemblages, occurring at levels above and below the Wormit samples, are all of lower Gedinnian age. The whole of the spore-bearing succession of the Arbuthnott Group, which is about $1,800 \mathrm{~m}$ thick, belongs to the micrornatusnewportensis Zone (lower and middle subzones) and is equivalent to part of the lower Ditton Group of Brown Clee Hill (Shropshire) of 20 to $30 \mathrm{~m}$ in thickness. There is no critical palaeontological evidence for age in the strata associated with the Arbuthnott Group, neither in the underlying Dunnottar and Crawton Groups nor in the overlying Garvock Group so the exact position of the Silurian-Devonian and Gedinnian-Siegenian boundaries is uncertain. A new spore Anteturma, namely Cryptosporites, is proposed. Qualisaspora fragilis gen. et sp. nov. is described herein and appears to have potential as an index fossil for the lower Ditonian of the British Isles. Some regional differences also occur as?Dibolisporites $\mathrm{sp}$. A and ? Samarisporites sp. A occur in beds dated as lower Gedinnian in Sotland whereas spores of similar sculpture and structure are present higher in the Anglo-Welsh sequence in beds dated as lower Siegenian.
\end{abstract}

\section{INTRODUCTION}

The Lower Old Red Sandstone sediments of the Midland Valley of Scotland, mainly sandstones and conglomerates, form an alpine-type molasse estimated to be more than $9 \mathrm{~km}$ thick in the Strathmore region. Fossils occur only sporadically throughout the Strathmore sequence, notably in the Cowie Harbour Fish-bed of the Stonehaven Group and in the Arbuthnott, Garvock and Strathmore Groups (Armstrong \& Paterson, 1970, table 1 and appendix 1). A Downtonian age has been proposed for the Cowie Harbour Fish-bed, its fauna of fish and arthropods being considered to be intermediate in character between those in Downton Castle Sandstone and the 'Psammosteus' Limestone of the AngloWelsh Borderland (Westoll, 1951, 1977). Vertebrates and eurypterids from the Arbuthnott Group were stated by Westoll to be "no older than the base of the Dittonian" (sensu White, 1950). Vertebrate fossils have been recovered only from the lower part of the Garvock Group and none have been found in the succeeding Strathmore Group.
Richardson (1967) reporting on a palynological reconnaissance in the Strathmore region, considered that spore assemblages from the Arbuthnott Group indicated an upper Dittonian (lower Siegenian) age and that spores from the Strathmore Group were Emsian. Following more extensive research similar conclusions were reported by Ford (Ph.D. thesis, 1971) and Holland \& Richardson (1977). Recently one of us (F. G.) obtained further assemblages from samples collected at Wormit Bay in northern Fife by Dr. M. F. Thirlwall. In the present study, these assemblages have been re-investigated, together with some of Ford's material, by one of us (J.B.R.), and their stratigraphical significance reassessed in the light of current palaeontological research, notably in the Welsh Borderlands and South Wales and Podolia.

The assemblages from Wormit are of particular interest as they occur in association with rocks considered by Thirlwall (1983) to be of Silurian age on the basis of radiometric dating. Although many of the Wormit spores are poorly preserved, they are nevertheless diagnostic. 


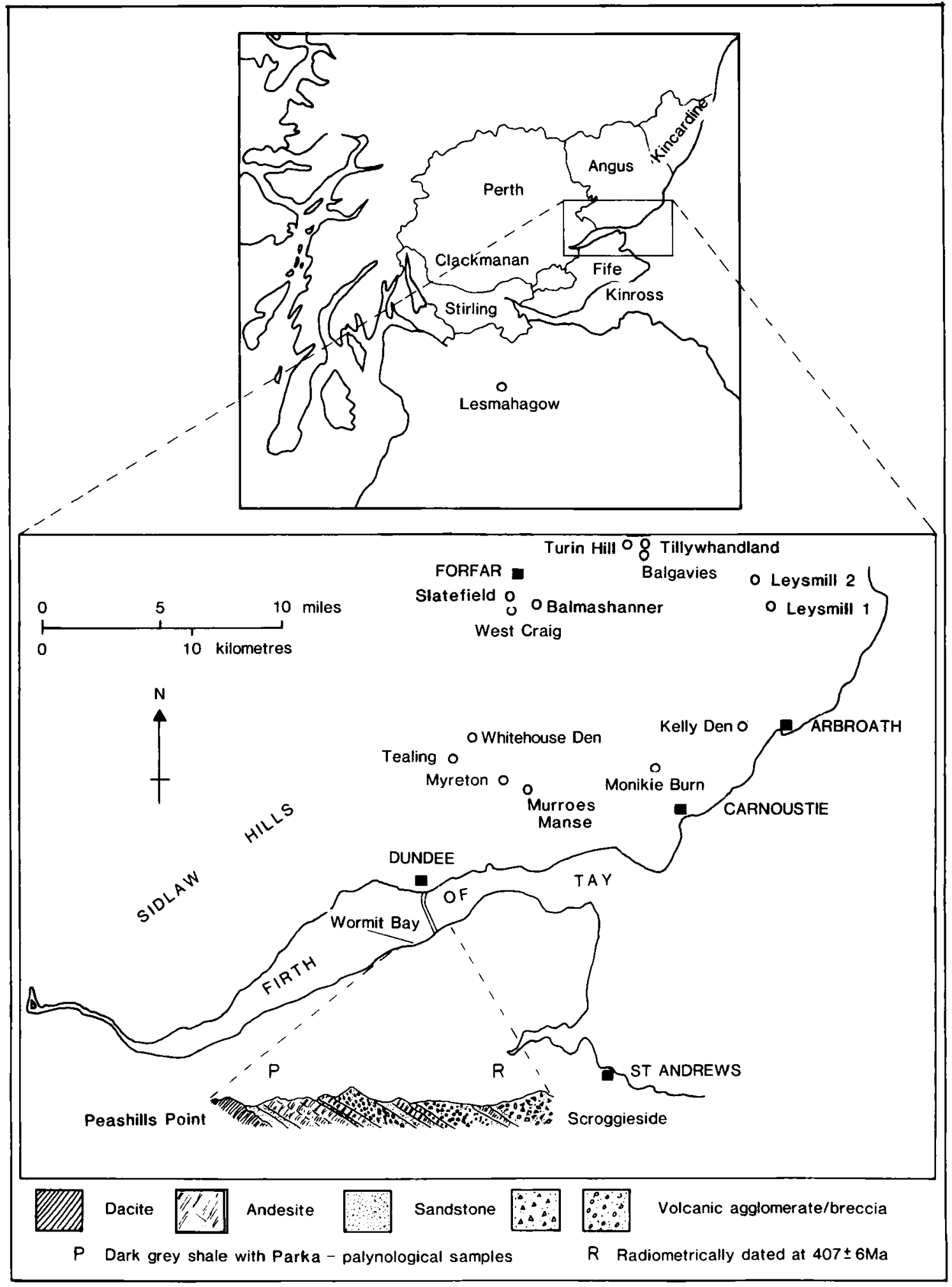

Fig. 1. Sample locations in Fife and Angus and section to show the relationship between the palynologically and radiometrically dated samples at Wormit Bay. The thickness of the geological section shown, from the top of the dacite at Peashills Point to the top of the agglomerates at Scroggieside, has been estimated to be 800 feet $(c .244 \mathrm{~m}) ;$ the thickness and the section are based on Geikie (1902, pp. 36-41). 
They not only allow correlation with Devonian miospore zones elsewhere, but provide a stratigraphical context in which Thirlwall's date can be used to refine the radiometric timescale.

\section{PALYNOLGY OF THE ARBUTHNOTT GROUP (FIFE AND ANGUS) (Fig. 2)}

The miospore assemblages from the Arbuthnott Group contain many of the species typical of the micrornatus-newportensis Zone in addition to the nominal (name) species; these additional species, some of which are new, are: Chelinospora cassicula Richardson \& Lister, $1969 ;$ C . vermiculata Chaloner \& Streel, 1968; C. sp. B; Cymbosporites dittonensis Richardson \& Lister, 1969; Emphanisporites epicautus Richardson \& Lister, 1969; Granulatasporites sp. A; Qualisaspora fragilis gen. et sp. nov.; Leonispora cf. argovejae Cramer \& Diez, 1975 and Perotrilites sp. A. None of these species has so far been recorded from strata other than the lower and middle Ditton Group and equivalents in the Anglo-Welsh region. There are, however, other species, typically associated in the assemblages of the micrornatus-newportensis Zone, which also occur outside the zone:-Retusotriletes cf. triangulatus sensu Richardson \& Lister, 1969; Synorisporites sp. D and Aneurospora sp. A. Some other species in the Arbuthnott Group (?Dibolisporites sp. A, ?D. sp $\mathrm{B}$, and ?Samarisporites sp. A have not yet been found in the Ditton Group. Consequently, there are some differences in the spore floras between the AngloWelsh area and Scotland but, in terms of the whole assemblage, the differences are relatively small. Nevertheless, sculptured zonate spores and biform sculpture of the kind seen in ?Dibolisporites are features which, in other areas, first appear in the Siegenian so it is interesting to note their seeming early appearance in the Scottish spore floras. Other spore "events" occur in the same sequence in the Scottish area and other regions.

Nine miospore assemblages from the Arbuthnott Group were investigated and compared with spores from the Ditton Group and lower Senni Beds (Fig. 2). Localities at Whitehouse Den, Myreton, Wormit, West Craig, Slatefield, Balmashanner, Tillywhandland, Murroes Manse and Monikie Burn all yielded spore assemblages and the data for all but the Wormit, Myreton and Balmashanner assemblages are based on a re-logging and re-investigation of Ford's thesis material. All these Arbuthnott Group assemblages are similar to

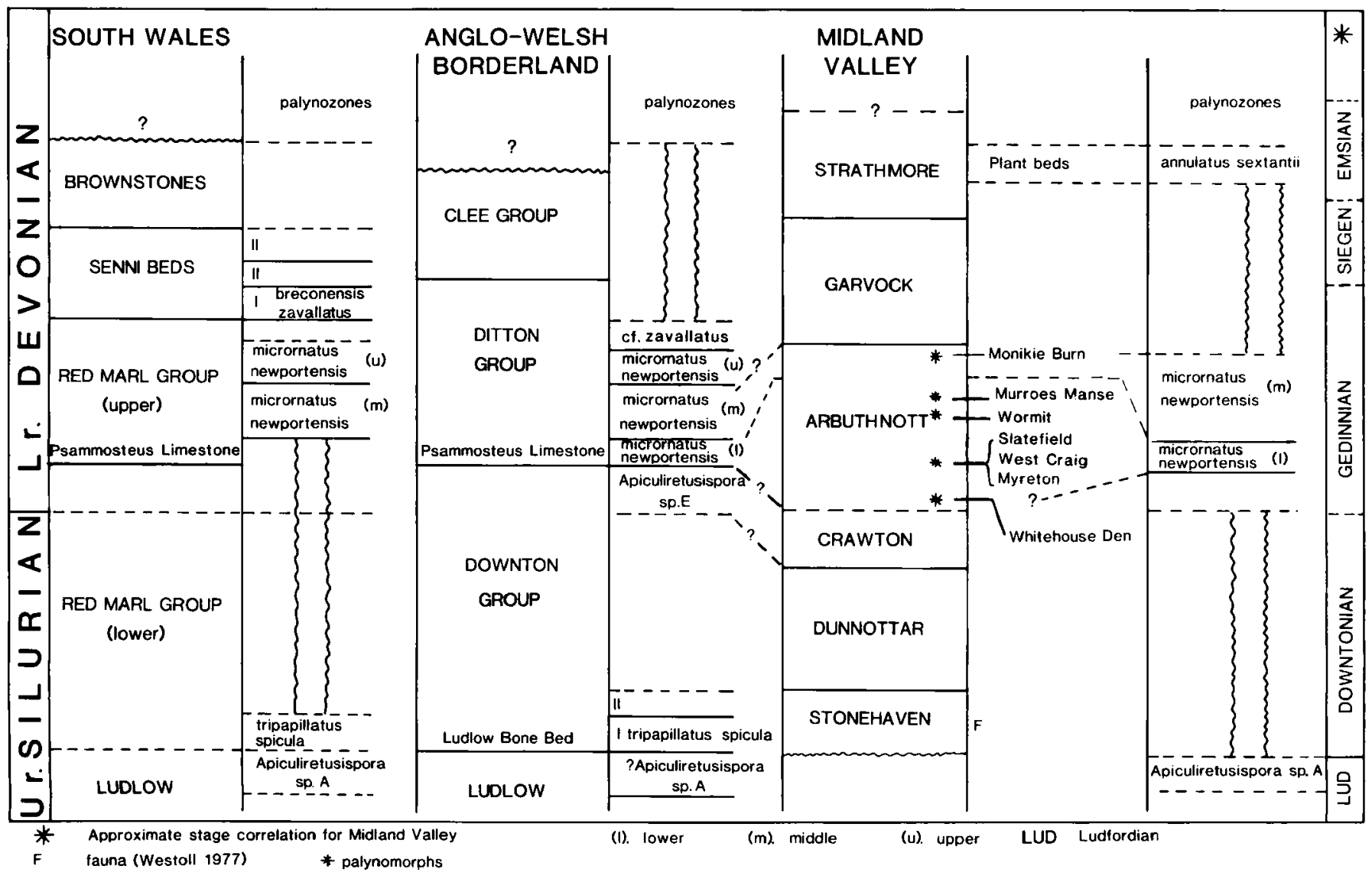

Fig. 2. Proposed correlation of the Arbuthnott Group assemblages with those from the Anglo-Welsh Borderland and South Wales. 
those from the lower Ditton Group of the Anglo-Welsh area, where the micrornatus-newportensis Zone (Richardson, 1974) may provisionally be divided into three subzones (Richardson, unpublished). The lowermost of these subzones is found throughout most of the Arbuthnott sequence. Only a few of the Scottish samples yielded spore assemblages with the species characteristic of the middle subzone and these were all from Monikie Burn high in the Arbuthnott Group.

The nine Arbuthnott Group assemblages are placed in a sequence based primarily on the mapping of Armstrong and Paterson (1970) which is largely supported and slightly modified by the spore evidence. However, the spore evidence indicates a similar age for all these assemblages. Of the eight assemblages correlated with the lowest micrornatus-newportensis Subzone, four of the upper six may be distinguished by the presence of sculptured-zonate spores (?Samarisporites $\mathrm{sp}$. A.) which are, however, comparatively rare. All the Arbuthnott Group assemblages compare closely with those studied by one of us (J.B.R.) from the lower part of the Ditton Group of Shropshire and equivalents in Hereford and Worcester. This is especially true of the West Craig assemblage which contains Chelinospora vermiculata, a species which in the Welsh Borderland is confined to the lower part of the Ditton Group.

Apart from the presence of ?Dibolisporites sp. and ?Samarisporites sp. A in the Scottish area, the differences between the spore assemblages of the Welsh Borderland are confined mainly to the relative abundance of species e.g. specimens of the genera Aneurospora and Streelispora in the latter area. Nevertheless, the records of many of the species common to both areas are confined to the lower Ditton Group and equivalents in the Welsh Borderland. The presence of $C$. vermiculata and the absence of Qualisaspora fragilis may indicate that the West Craig assemblage is older than Wormit but, as $C$. vermiculata is rare in the Arbuthnott Group and $Q$. fragilis is rare in the Welsh Borderland, the differences in the two areas are possibly due to lateral distribution factors. The spore assemblages from Whitehouse Den (regarded as the lowest of the fossiliferous horizons of the Arbuthnott Group covered in this paper, Armstrong \& Paterson, 1970), Myreton, Wormit, West Craig, Slatefield and Balmashanner, Murroes Manse and Tillywhandland can be correlated with the lowest subzone of the micrornatus-newportensis Zone and those from Monikie Burn belong to the second (middle) subzone. The species Emphanisporites micrornatus s.s. occurs in the samples here studied only in the Monikie Burn assemblages. It is characteristic of the upper lower and middle Ditton Group but does not occur in the Senni Beds belonging to the succeeding breconensiszavallatus Zone (Richardson et al., 1982). E. micrornatus characterises both the middle and upper subzones of the micrornatus-newportensis Zone but none of the species indicative of the upper subzone have been found in the Arbuthnott Group. The Monikie Burn assemblages are therefore thought to belong to the middle subzone of the micrornatus-newportensis Zone and most likely to the lower part of this subzone.

The presence of ?Dibolisporites and ?Samarisporites and the rarity of spores of the Aneurospora-Streelispora complex are the main differences between the Arbuthnott Group assemblages and those from the same zonal position in the Welsh Borderland. In the Anglo-Welsh area representatives of the genus Dibolisporites first appear in the lower (but not the lowest) part of the Senni Beds. Their first appearance in that area marks the top of the breconensis-zavallatus Zone whereas the Arbuthnott specimens (?Dibolisporites) occur in the lower part of the preceding zone (micrornatus-newportensis). Because of the occurrence of ?Dibolisporites and sculptured zonate forms (?Samarisporites sp. A), it was previously considered that the Scottish assemblages were intermediate in age between the middle Ditton Group and Senni Beds and therefore equivalent to the upper Ditton Group (Westoll, p. 73 in House et al., 1977). At that time, the upper Ditton Group was still correlated with the lower Siegenian on the basis of vertebrates, but recent work demonstrates an upper Gedinnian age (Blieck \& Jahnke, 1980). Consequently, prior to the work of Blieck and Jahnke and the new miospore work in the Welsh Borderland (J.B.R. unpublished) and in South Wales (Hassan, unpublished), the Scottish assemblages were considered to be upper Dittonian and therefore lower Siegenian. The Anglo-Welsh assemblages are now better known and good assemblages are now known from a number of localities in the Welsh Borderland and South Wales. Comparisons show marked correspondence between assemblages from the Arbuthnott Group and those from the lower Ditton Group. Consequently, the Arbuthnott Group from Fife and Angus is here regarded as equivalent to the lower Ditton Group (leathensis vertebrate Zone).

\section{CORRELATION WITH STAGE AND SYSTEM BOUNDARIES (Fig. 3)}

The age of the Ditton Group (Richardson et al., 1981), and hence now its part correlative, the Arbuthnott Group, in relation to the Silurian-Devonian boundary and to international stage boundaries can be determined on the basis of spore correlation. The base of the micrornatus-newportensis Zone in the Welsh Borderland begins just above the 'Psammosteus' Limestone which is basal Ditton Group (basal Dittonian) sensu Whitehead \& Pocock, 1947 and Ball \& Dineley, 1961. In the upper Downtonian below the micrornatusnewportensis Zone, a distinct assemblage occurs, referred to herein as the Apiculiretusispora sp. E assemblage. Both these zonal assemblages are correlated with 
marine Lower Devonian strata by comparison with spore and graptolite-bearing sequences in Podolia (Richardson et al., 1981) where the Silurian-Devonian boundary is placed at the base of the Borshchov "Horizon" (Stage) between the Dzwinogorod and Tajna Beds. Monograptus uniformis angustidens occurs at the base of the Tajna Beds and trilobites, brachiopods, conodonts and crinoids typical of the the uppermost Silurian have been found in the Dzwinogorod Beds below (Nikiforova, 1977). Arkhangelskaya (1980) recorded spores at four stratigraphical levels in the Podolian region (from the region of the upper Dniester and its tributaries) and, in ascending sequence these are as follows: the middle of the Borshchov "Horizon" (Stage) (Mitkov Beds, outcrop 51 of Nikiforova and Predtechensky, 1968), the Chortkov "Horizon" (outcrop 81), the Ivane "Horizon" (outcrop 58) and the Ustechko "Horizon" (outcrop 116). The Borshchov, Chortkov and Ivane "Horizons" belong to the Tiver Series ("Superhorizon") and the Ustechko "Horizon" to the Dniester Series. Spore assemblages which are correlated with the micrornatus-newportensis Zone occur in the Chortkov and Ivane "Horizons" and prob- ably belong to the lower and middle subzones of the micrornatus-newportensis Zone. The lowest assemblages from the Mitkov Beds resemble those from the Apiculiretusispora sp. E "zone" and the spores illustrated by Arkangelskaya (1980) do not contain any of the species diagnostic of the micrornatus-newportensis Zone. Thus, most, if not all, the Borshchov "Horizon" is older than the basal Dittonian (micrornatus-newportensis Zone) and therefore older than the samples from the Arbuthnott Group. The beds of Chortkov "Horizon" contain assemblages comparable with the lower, middle and lower upper Arbuthnott Group and the Ivane "Horizon" may be correlated with the uppermost Arbuthnott Group and possibly younger beds within the middle subzone. Too few spore assemblages have been described from Podolia for the spore subzone boundaries to be recognised precisely. Nevertheless, the assemblages figured by Arkangelskaya are sufficient to date the Arbuthnott Group in terms of the Podolian marine sequence and the latter can be correlated by means of graptolites and other marine invertebrates with the type section for the Silurian-Devonian Boundary at Klonk. The Borshchov "Horizon" (Stage) and

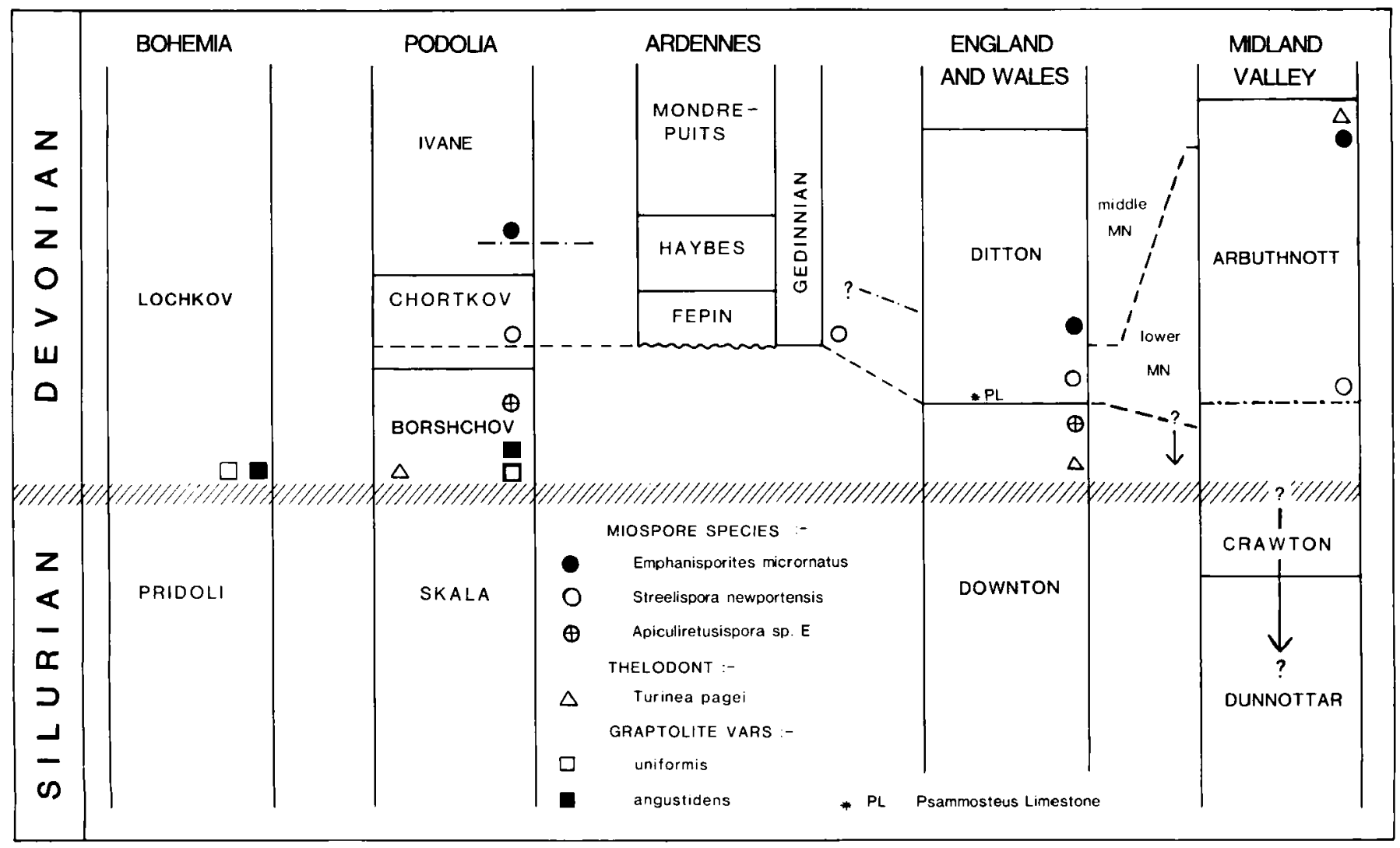

Fig. 3. Correlation of the lower and middle subzones of the micrornatus-newportensis Zone with the Silurian-Devonian Boundary. Symbols depict the first known occurrences of the faunal and floral elements. 
Table 1. Presumed relation of sampled horizons to stratigraphy of the Arbuthnott Group in north Fife and Angus. Based on data from Armstrong and Paterson, pers. comm.

south-east limb of Sidlaw Anticline

north-west limb of Sidlaw Anticline

\begin{tabular}{clll}
\hline $\begin{array}{c}\text { MN } \\
\text { (middle subzone) }\end{array}$ & $\begin{array}{c}\text { south-west } \\
\text { MONIKIE BURN (Q.) }\end{array}$ & \multicolumn{1}{c}{$\begin{array}{c}\text { north-east } \\
\text { (KELLY DEN HORIZON) }\end{array}$} & (ABERLEMNO HORIZON) \\
\hline $\begin{array}{c}\text { MN } \\
\text { (lower subzone) }\end{array}$ & $\begin{array}{l}\text { (Tayport-Wormit } \\
\text { Lavas) } \\
407 \pm 6 \mathrm{Ma} \\
\text { WORMIT BAY (Q) }\end{array}$ & (Broughty Ferry Lavas) & TURIN HILL \\
& MURROES MANSE (Z) & TILLYWHANDLAND (Z) \\
& MYRETON (Q) ?LEYSMILL & SLATEFIELD (Q, Z) BALGAVIES \\
& & WEST CRAIG (Z, V)
\end{tabular}

WHITEHOUSE DEN

Base of Arbuthnott Group unknown in Fife and Angus (horizon of the Crawton Lavas presumed to be a short distance below the exposed sequence).

Spore data: $\mathrm{Q}=Q$. fragilis, $\mathrm{V}=$ Chelinospora vermiculata, $\mathrm{Z}=$ zonate spores, ?Samarisporites $\mathrm{sp}$. A.

succeeding Chortkov and Ivane "Horizons" are all above a well demarcated Silurian-Devonian boundary. The presence of Monograptus uniformis angustidens, Icriodus woschmidti, Acastella heberti with other species in the base of the Tajna Beds show that the latter strata can be assigned to the base of the Devonian System (Nikiforova, 1977). Correlation with the Podolian sequence shows that the Arbuthnott Group is younger than basal Devonian and, in Scotland, deposits of a premicrornatus-newportensis 'zone' equivalent to the Tajna and Mitkov Beds of the Borshchov "Horizon" must lie below (i.e. the Arbuthnott Group). No spores have been described from the Bogdanovka Beds, upper Borshchov "Horizon" which may be either premicrornatus-newportensis or equivalent to the lowermost part of the latter zone. So the equivalents of the Bogdanovka Beds may also lie beneath the Arbuthnott Group.

Correlations with Podolia show that strata containing the micrornatus-newportensis Zone are Lower Devonian in age. Further, the micrornatus-newportensis Zone has also been found in the lower Gedinnian, the type area in Belgium, where Steemans (1982) has recorded the micrornatus-newportensis Zone assemblage (proably from the lower subzone, Richardson unpubl.) from the Fepin Conglomerate and the Haybes Beds. The same spore zone has also been recorded from upper Fooz Beds equated with the lower part of the upper Gedinnian (Richardson et al, 1982) probably equivalent in part to the middle subzone. This middle subzone is probably equivalent to part of the micrornatus interval zone of Steemans (1982). Although much work remains to be done, our correlation places the whole of the Arbuthnott Group within the lower Gedinnian.

\section{THE POSITION OF THE SILURIAN-DEVONIAN BOUNDARY IN THE STRATHMORE REGION}

(Fig. 3)

Assemblages typical of the basal Devonian have so far not been found in the Strathmore Region. In the Welsh Borderland, the base of the mirornatus-newportensis Zone is at least $21 \mathrm{~m}$ above the inferred position of the Silurian-Devonian boundary based on thelodonts (Turner, 1973). In view of the coarser nature of the Scottish deposits, however, and the presence of lavas in the Strathmore sequences, there is probably a much greater thickness of Devonian strata lying below the base of the micrornatus-newportensis Zone in the Strathmore Region than in the Welsh Borderland. We regard the Whitehouse Den assemblage as the lowest sample in the Strathmore sequences studied. Since it belongs to the lower micrornatus-newportensis Zone, the Silurian-Devonian Boundary in the Strathmore Region must be some way below the Whitehouse Den level. According to the sections published by Armstrong and Paterson (1970, fig. 4), the Whitehouse Den horizon (Angus), equivalent to the Tealing Horizon (Armstrong \& Paterson, 1970, appendix II) approximates to the top of the Crawton Group of Kincardineshire (ibid., text-fig. 6).

If the Silurian-Devonian Boundary is located in the upper Crawton Group, or near the boundary between 
the Crawton and Arbuthnott Groups, then the whole of the Stonehaven and Dunnottar Groups, and most, or all, of the Crawton Group would be Silurian in age. There is no direct palynological evidence for this as none of the Kincardine samples has been productive. Much of the sequence consists of rocks, such as lavas and coarse clastics, totally unsuited to the preservation of palynomorphs but several attempts have been made to obtain palynomorphs from the Cowie Harbour Fish Bed and associated sediments (Stonehaven Group). If the SilurianDevonian Boundary is near the base of the Arbuthnott Group and the Stonehaven Group is Downtonian (Westoll, 1945, 1977), then the Downtonian in the Strathmore region is represented by approximately $4,000 \mathrm{~m}$ of strata (this compares with $c .500 \mathrm{~m}$ of sediments in the Downtonian of the Clee Hills and Hereford and Worcester). However, Devonian strata do occur below the micrornatus-newportensis Zone in the Podolian succession and in the Welsh Borderland. For example, floras probably indicating an early Devonian age occur c. $39 \mathrm{~m}$ below the base of the St. Maughan's Group in Worcester and Hereford (Richardson, unpublished). What sort of thickness does this represent in the Scottish sequence? A comparison of the thickness of the part of the micrornatus-newportensis Zone represented by the Arbuthnott Group and the equivalent strata in the Brown Clee Hill is around $2,000 \mathrm{~m}$ as against $20-30 \mathrm{~m}$. If we accept the higher figure for Brown Clee of $30 \mathrm{~m}$, then the Scottish equivalents of these Dittonian sediments are around 67 times greater in thickness. If we apply the same factor to the beds below the micrornatusnewportensis Zone, then at least 2,600 $\mathrm{m}$ of Devonian strata would underlie the Arbuthnott Group. This comparison would put the Silurian-Devonian Boundary not far below the incoming of coarse conglomerate which marks the base of the Dunnottar Group. Such comparisons, however, can only suggest an approximate answer, pending the discovery of fossils.

\section{RADIOMETRIC DATING OF THE ARBUTHNOTT GROUP (MICRORNATUS-NEWPORTENSIS ZONE)} (Fig. 1)

A radiometric age of $407 \pm 6 \mathrm{Ma}$ has been obtained by Thirlwall (1983) for the lower part of the Arbuthnott Group. One sample dated was obtained from a rhyolitic boulder in conglomerate ("agglomerate/breccia" of Geikie) that occurs at the top of the sequence described by Geikie (1902). The conglomerate overlies a sequence of lavas and sediments over $200 \mathrm{~m}$ in thickness but is near the base of the lava sequence in the TayportWormit area and at a higher stratigraphical level than the $1.8 \mathrm{~m}$ fossiliferous shale intercalation sampled at Wormit from which we have obtained spores of the lower subzone of the micrornatus-newportensis Zone. On the basis of the above date Thirlwell suggested that the Arbuthnott Group volcanic sequence might be of Silurian age. The miospore evidence now shows that the entire Arbuthnott Group is of Lower Devonian age.

There is at least part of one spore zone within the Devonian below the micrornatus-newportensis Zone in Podolia and the Anglo-Welsh area but in these areas the position of the lower boundary of this premicrornatus-newportensis Zone in relation to the Silurian-Devonian Boundary is uncertain. The average duration for a major inter-regional spore zone is estimated at about 3 to 4 million years, though this is based on too few radiometric dates. If so, then accepting Thirlwall's date and assuming a completely Devonian pre-micrornatus-newportensis Zone of $3 \mathrm{Ma}$, we obtain an age of $410 \pm 6 \mathrm{Ma}$ for the base of the Devonian. A further relevant date was obtained by Thirlwall from the Lintrathen Ignimbrite which is thought by Armstrong \& Paterson (1978) to lie immediately below the base of the Arbuthnott Group. If the tentative argument that the Devonian base in Strathmore is close to the base of the Dunnottar Group is valid, then an age for the base of the Devonian of about $415 \mathrm{Ma}$ is possible. The figure given by Harland et al. (1982) for the beginning of the Devonian is $408 \mathrm{Ma}$. McKerrowet al. (1980) use a series of dates to plot an age for the Silurian-Devonian Boundary. The dates nearest to the base of the Devonian are: 1) a post-Wenlock and pre-Siegenian date for the Gocup Granite of New South Wales (McKerrow, Lambert \& Chamberlain, 1980; with a $\mathrm{K}-\mathrm{Ar}$ age of $409 \pm 3 \mathrm{Ma}$; 2) a fission track dating of zircons from bentonites in the Bringewood Beds (Gorstian Stage, Silurian) which gave an age of $407 \pm 8 \mathrm{Ma}$. Thirlwall's date can now be shown to be much closer to the SilurianDevonian Boundary than the best of those determined hitherto. As far as we are aware, nowhere else in the Lower Devonian has such a close relationship been demonstrated between rocks dated by the absolute and relative methods. Further, though the Arbuthnott Group is Devonian in age, and not Silurian as Thirlwall supposed, these beds are much closer to the SilurianDevonian Boundary than any other group dated radiometrically. Consequently Thirlwall's dates could become a standard by which the accuracy of previous age determinations for the base of the Devonian System may be re-assessed.

In a series of papers Thirlwall has agreed that the Arbuthnott Group volcanic activity was generated by active subduction associated with the final closure of the Iapetus Ocean. Assuming that the hypothesis remains valid, it would appear that subduction continued into the Lower Devonian period. 


\section{CONCLUSIONS}

It is now possible to correlate parts of the Strathmore sequence more precisely with the Anglo-Welsh cuvette, the type area of the Gedinnian Stage in the Ardennes, and also with graptolite - bearing sequences above the Silurian-Devonian Boundary in Podolia. In turn, the Podolian sequence can be correlated, on the basis of graptolites, with the stratotype sequence for the SilurianDevonian Boundary at Klonk, Czechoslovakia.

The miospore data provides evidence that all the Arbuthnott Group exposed in Angus is Devonian in age and that all the spore assemblages through approximately $1,800 \mathrm{~m}$ of strata are lower Gedinnian. The lowest spore assemblages are lower but not basal Gedinnian (Devonian) and consequently an unknown thickness of Devonian strata lies below. This may include lower, unexposed parts of the Arbuthnott Group, part or all of the Crawton Group, the Dunnottar Group and possibly part of the Stonehaven Group.

The rocks at Wormit from which the radiometric date was obtained by Thirlwall are associated with palynological assemblages dated as lower but not lowermost Gedinnian and are therefore Devonian and not Silurian as suggested by Thirlwall.

The age of the base of the Devonian is probably about $410 \mathrm{Ma}$, but may be as great as $415 \mathrm{Ma}$. Activity on the Solway subduction zone, on the evidence of volcanic rocks, may have continued into the lower Devonian. If during this period the Scottish and Anglo-Welsh Provinces were separated by a remnant of the Iapetus Ocean, this might account for the observed differences between the spore assemblages from the two areas though, in general, the microflora of the Scottish and the Anglo-Welsh areas are closely similar. The macroflora from the Strathmore region, on the other hand, corresponds to the Anglo-Welsh area at the generic but not the specific level (Dianne Edwards, pers. comm.) a fact that may be due to the vicissitudes of preservation and/or the different environmental and depositional factors that prevailed in the two areas.

\section{SYSTEMATIC DESCRIPTIONS}

All slides are identified by letters and numbers listed in the appendix giving details of the localities. Slides with a $\mathrm{J}$ or JO prefix were prepared by Ford, those with a Wormit prefix were collected by Dr. M. F. Thirlwall and prepared by Parker at the University of Sheffield; four slides designated Scotland $8 \mathrm{~A} \& \mathrm{~B}$ were given to one of us (J.B.R.) by the late Dr. Huon Walton and the remainder of the slides, designated by locality and MV numbers, were collected by Richardson and prepared in the Department of Geology, King's College, London. The figured and described specimens are all given an FM prefix and are in the collections of the Palynology Section, Department of Palaeontology, British Museum (Natural History), London.

Anteturma Cryptosporites anteturma nov.

Definition. Non-marine sporomorphs (non-pollen grains) with no visible haptotypic features such as contact areas or tetrad marks. Single grains or monads, "permanent" dyads and tetrads are included.

Remarks. Cryptospores are most common in continental Silurian rocks (see Strother \& Traverse, 1979). They are distinguished from spores which have well differentiated contact areas but no tetrad mark which are regarded here as alete miospores, some of which may have formed in dyads or tetrads. "Permanent" dyads and tetrads, where the nature of the contact face is unknown, are also regarded as cryptospores. The affinities of the cryptospores are unknown.

\section{Explanation of Plate 1}

All figures are $\times 2,000$, except where otherwise stated, and were photographed using Nomarski differential interference contrast. The sample and slide numbers are followed by specimen co-ordinates obtained with a Zeiss photomicroscope II, no. 65800 .

Figs. 1, 2. Qualisaspora fragilis gen. et sp. nov.: fig. 1, holotype, Wormit slide 10 C, 058 1057, showing radial muri enveloping both surfaces and the central body, FM68; fig. 2, Slatefield, slide 24/3/118, 0950845 , showing ?apical and peripheral thickenings, FM87.

Figs. 3, 4. Streelispora newportensis (Chaloner \& Streel) Richardson \& Lister, 1969; Monikie Burn, slide J031C'196, 095 0944: fig. 3, proximal surface showing folds; fig. 4, distal surface showing grana and coni, FM 69, X1,000.

Fig. 5 Emphanisporites micrornatus Richardson \& Lister, 1969; Monikie Burn, slide J031 A 182, 127 1010; tipped specimen with fine distal grana, FM 70.

Figs. 6, 7. Emphanisporites cf. novellus Mcgregor \& Camfield, 1976; Murroes Manse, slide 20/2/31, 129 0871: fig. 6, proximal view showing curvature; fig. 7 , distal focus showing coarse, close packed grana, FM 71. 

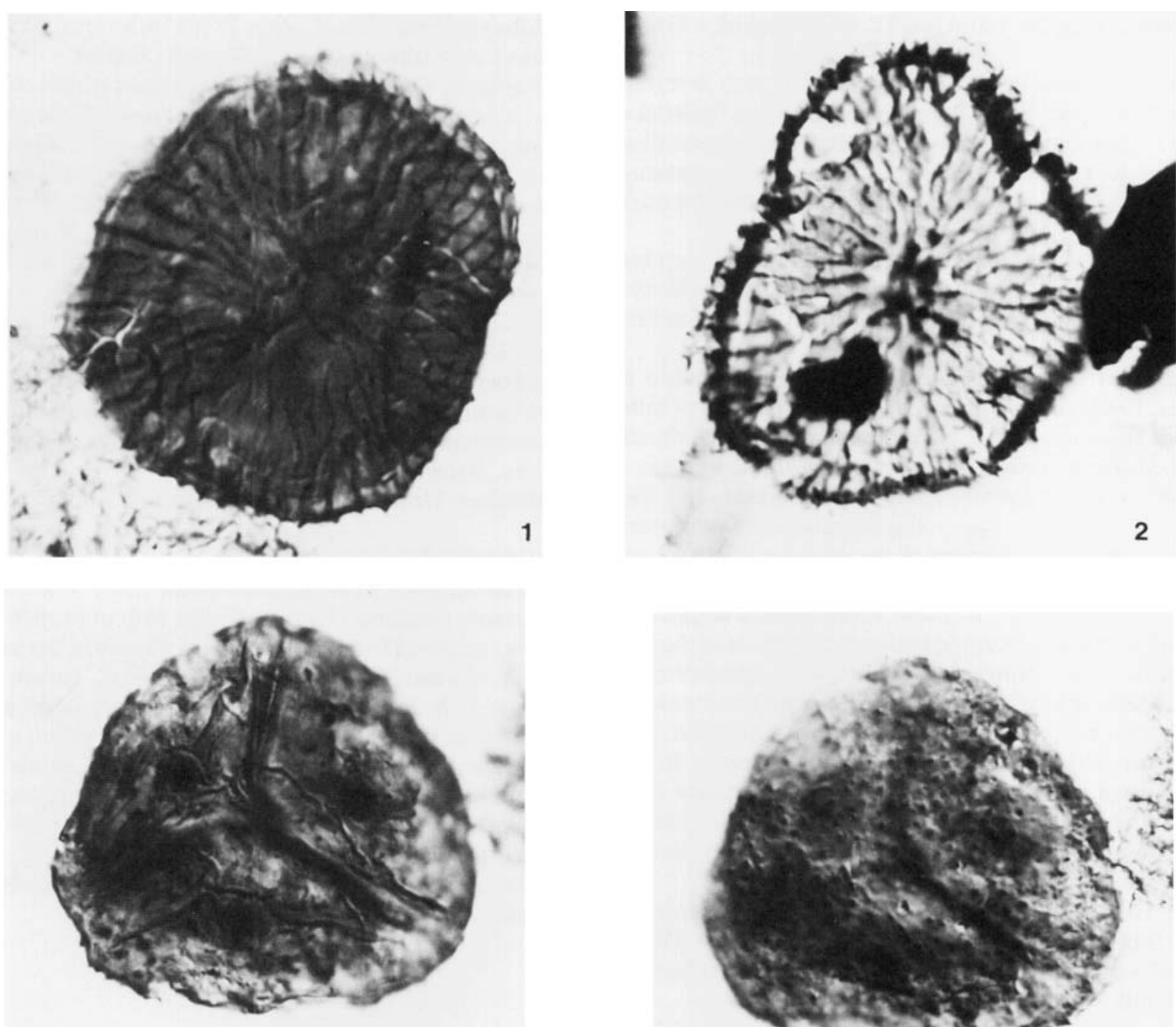

3
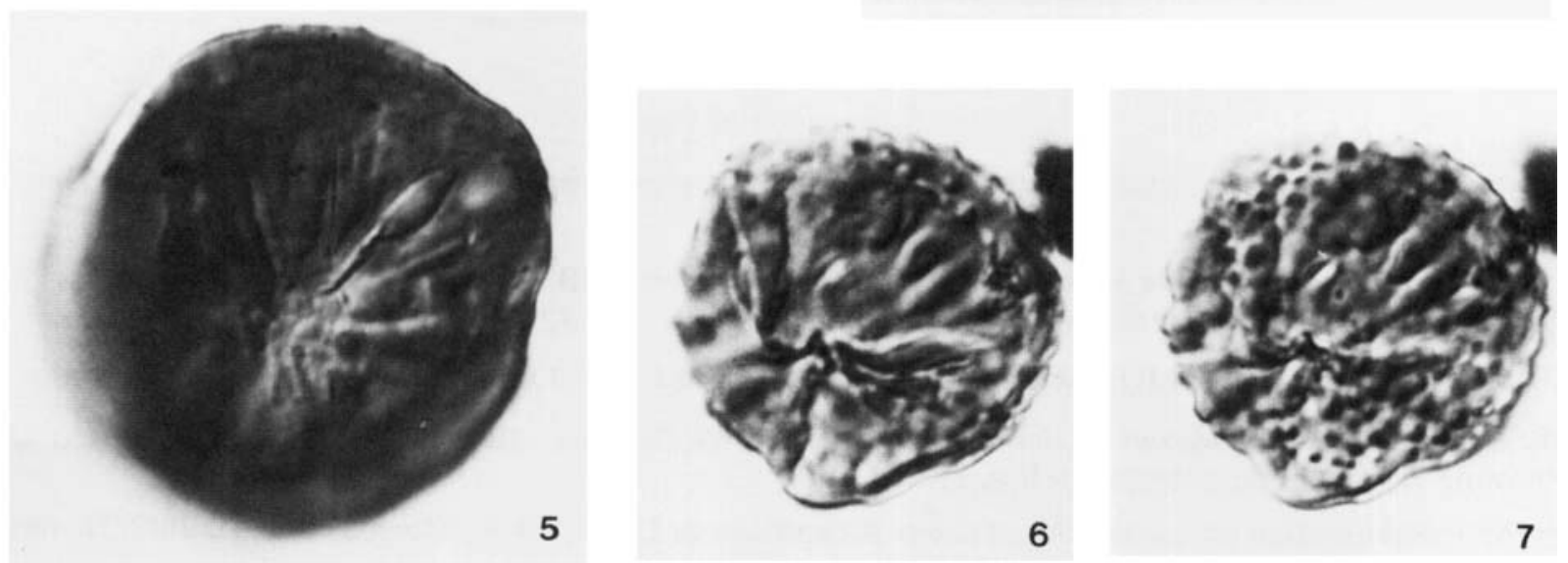
Genus Qualisaspora gen. nov.

Type species. Qualisaspora fragilis sp. nov. Derivation of name. Latin qualis, what kind of, + Greek spora, spore.

Diagnosis. Monad cryptospores which are two-layered; outer ("exoexine") thin, inner layer ("intexine") distinct, thicker than exoexine and separated from it; outline rounded to rounded triangular. Exoexine sculptured over entire sporomorph by radial muri which converge at two foci on opposite surfaces.

Description. No haptotypic features have been seen but an elongate fold occurs on one surface in some specimens. Sporomorphs most frequently occur in a fragmentary condition.

Comparison and remarks. Strophomorpha Miller \& Eames, 1982 is elongate, has a helicoidal pattern of muri or folds and apparently lacks a double wall. The acritarch genus Moyeria is similar to Strophomorpha but has a thinner wall. Strophomorpha and Moyeria are like Qualisaspora in having a single pattern of sculpture covering the entire surface of the sporomorph and not just one hemisphere as in most Silurian and Devonian spores. Further, none of these three genera shows any indication that they formed in dyads or tetrads as they do not show any differentiation into two hemispheres, contact features, or tetrad marks. Because the nature of their formation, and their affinities, are uncertain, and also because they differ from most other spores in the late Silurian and early Devonian, such spores are here termed cryptospores (kryptos, Greek, hidden). Similar spores are known from rocks as old as Lower Silurian (Rhuddanian) (Miller \& Eames, 1982).

The foci of the muri may be central or excentric suggesting either that the sporomorphs may have been originally more or less spherical and/or the outer layer is completely separate from the inner one.
Qualisaspora fragilis sp. nov.

(Pl. 1, figs. 1-2)

Holotype. Size $33 \mu \mathrm{m}$; slide W10C reference 058 1057; lower Arbuthnott Group, Wormit; FM 68.

Diagnosis. Outer layer thin; bears muri which converge on a small ring on one surface and towards an elongate central area on the the other where the central body may be thickened; muri thickened, diverge radially from two foci and dichotomise once or twice before reaching the periphery where they project like small spines.

Description. Foci of muri more or less central but may be excentric; one focus forms a murate ring c. $2 \mu \mathrm{m}$ in diameter; muri less than $1 \mu \mathrm{m}$ high and wide. Size range: 27-39 $\mu \mathrm{m}$ (based on 31 specimens).

Occurrence. Found in most productive samples of the Arbuthnott Group Fife and Angus (Scotland), also present in the upper part of the leathensis vertebrate zone, Brown Clee Hill.

Affinites. Unknown; possibily algal or fungal.

\section{ACKNOWLEDGEMENTS}

The authors would like to thank Peter York, British Museum (Natural History) for his help in preparing the photographs. Dr. M. F. Thirlwall for some of the samples from Wormit; Dr. R. H. Bate, Dr. M. K. Howarth and Dr. R. P. S. Jefferies for reading the manuscript and for helpful advice; Dr. M. Armstrong for revising parts of the text and, together with Dr. I. Paterson, made useful comments on the stratigraphy of the Strathmore area; Mrs. C. Bell for making up the plates and for assistance with the diagrams.

Jancis Ford was supported by a grant from the Natural Environment Research Council.

\section{Explanation of Plate 2}

All figures are $\times 2,000$, except where otherwise stated, and were photographed using Nomarski differential interference contrast.

Figs. 1,2. Chelinospora cassicula Richardson \& Lister, 1969; Wormit 2B/2, 1801304 : fig. 1, showing broad polygonal pattern of membranous muri; fig. 2, showing muri in profile, FM 72.

Fig. 3. ?Dibolisporites sp. A; Myreton 8 A \& B/1, 120 0971, FM 73, × 1,000.

Fig. 4. Emphanisporites epicautus Richardson \& Lister, 1969; Wormit, 2B/2, 149 1169; slightly tipped specimen showing curvaturae and thickened lips, FM 74.

Fig. 5, 6. Cymbosporites cf. catillus Allen sensu Richardson \& Lister, 1969; Murroes Manse, 20/2/31, 061 0920; proximal and distal focus respectively, FM 75.

Fig. 7. Aneurospora sp. A; Slatefield, 24/7/483, 065 0951, FM 76. 

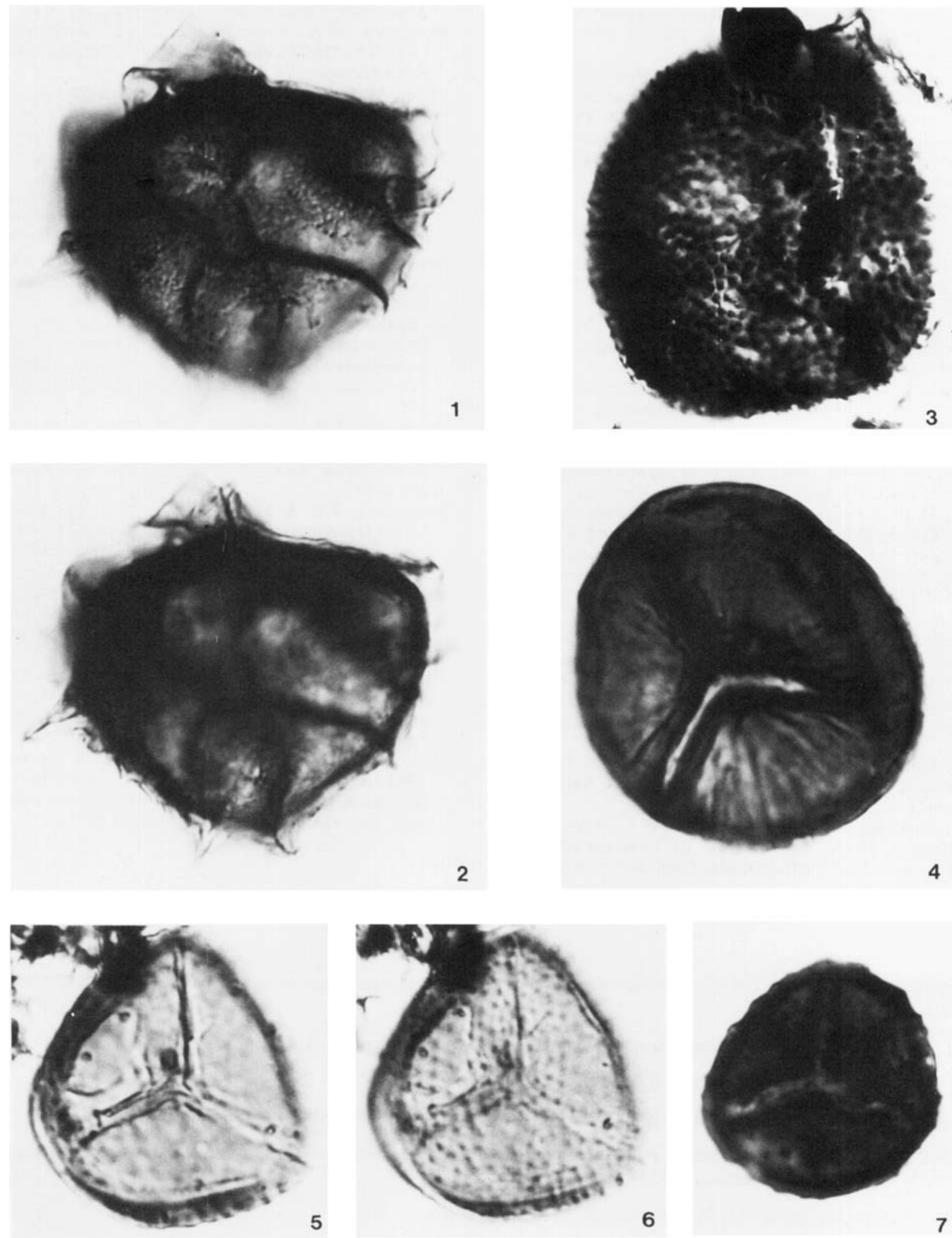


\section{REFERENCES}

Allen, J.R.L. \& Dineley, D.L. 1976. The succession of the lower Old Red Sandstone (Siluro-Devonian) along the Ross-Tewkesbury Spur Motorway (M.50), Hereford and Worcester. Geol. J., 11, 2-14.

Arkhangelskaya, A.D. 1980. Plant spores from some Lower Devonian sections of the western regions of the Russian Platform (in Russian). TRUDY VNIGNI (Moscow): Palynological research in the Proterozoic and Phanerozoic of oil- and gas-bearing regions of the USSR, 217, 26-46, 140-143, pls. 5-11.

Armstrong, M. \& Paterson, I. B. 1970. The Lower Old Red Sandstone of the Strathmore Region. Inst. Geol. Sci. Rep. no. 70/12, 1-23.

Ball, H.W. \& Dineley, D.L. 1961. The Old Red Sandstone of Brown Clee Hill and the adjacent area. Bull. Br. Mus. Nat. Hist., London, A5, 18-242.

Blieck, A. \& Jahnke, H. 1980. Pteraspiden (Vertebrata, Heterostraci) aus den Unteren Siegener Schichten. $N$. Jb. Geol. Palaont., 159(3), 360-378.

Chaloner, W.G. \& Streel, M. 1968. Lower Devonian spores from South Wales. Argumenta Palaeobotanica, 1, 87-101, pls. 19-20.

Cramer, F.H. \& Diez, M. del C.R. 1975. Earliest Devonian miospores from the province of Leon, Spain. Pollen spores, 17, 331-344, pls. 1-2.

Ford, J.H. 1971.Palynology of some Upper Silurian and Lower old Red Sandstone sediments in the Midland Valley of Scotland. Unpub. Ph. D. thesis, University of London.

Geikie, A. 1902. The geology of eastern Fife. Mem. Geol. Surv. Gt. Brit. \& Ire.

Graham, J. R., Richardson, J. B. \& Clayton, G. 1983. Age and significance of the Old Red Sandstone around Clew Bay, N. W. Ireland. Trans. R. Soc. Edinburgh, 73, 245-247, 1 pl.

Harland, W. B., Cox, A. V., Llewellyn, P. G., Pickton, C. A. G., Smith, A.G. \& Walters, R. 1982. A geologic time scale. Cambridge Earth Science Series, Cambridge University Press.

Holland, C.H. \& Richardson, J.B. 1977. The British Isles. The Silurian-Devonian Boundary. IUGS Series A, Stuttgart, 5, $35-44$.

House, M. R., Richardson, J.B., Chaloner, W. G., Allen, J. R. L., Holland, C.H. \& Westoll, T.S. 1977. A correlation of Devonian rocks of the British Isles. Geol. Soc. Lond., Special Report, 8, 110 pp.
McGregor, D.C. \& Camfield, M. 1976. Upper Silurian? to Middle Devonian spores of the Moose River Basin, Ontario. Geol. Surv. Canada, Bull., 263, 63 pp., pls. 1-8.

McKerrow, W.S., Lambert, R.St.J. \& Chamberlain, V.E. 1980. The Ordovician, Silurian and Devonian time scales. Earth Planetary Sci. Letters,51, 1-8.

Miller, M.A. \& Eames, L.E. 1982. Palynomorphs from the Silurian Medina Group (Lower Llandovery) of the Niagara Gorge, Lewiston, New York, U.S.A.Palynology, 6, 221-254.

Nikiforova, O.I. 1977. Podolia. The Silurian-Devonian Boundary. IUGS Series A, Stuttgart, 5, 52-64.

Nikiforova, O.I. \& Predtechensky, N.N. 1968. A guide to the geological excursion on Silurian and Lower Devonian deposits of Podolia. (Middle Dniestr River). Int. Symposium Silurian.

Richardson, J.B. 1967. Some British Lower Devonian spore assemblages and their stratigraphic significance. Rev. Palaeobotan. Palynol., 1, 111-129, pls. 1-4.

Richardson, J.B. 1974. The stratigraphic utilization of some Silurian and Devonian miospores species in the northern hemisphere: an attempt at a synthesis. International Symposium on Belgian Micropaleontological limits No. 9, $1-13$.

Richardson, J. B. \& Ioannides, N. 1973. Silurian palynomorphs from the Tanezzuft and Acacus Formations, Tripolitania, North Africa. Micropaleontology, New York, 19, 257-307, pls. 1-13.

Richardson, J.B. \& Lister, T.R. 1969. Upper Silurian and Lower Devonian spore assemblages from the Welsh Borderland and South Wales.Palaeontology, London, 12, 201-252, pls. 37-43.

Richardson, J.B. \& Rasul, S. M. 1979. Palynological evidence for the age and provenance of the Lower Old Red Sandstone from the Apley Barn Borehole, Witney, Oxfordshire. Proc. Geol. Ass., London, 90, 27-42, pls. 1-2.

Richardson, J. B., Rasul, S. M. \& Al-Ameri, T. 1981 . Acritarchs, miospores and correlation of the Ludlovian-Downtonian and Silurian-Devonian boundaries. Rev. Palaeobotan. Palynol., 34, 209-224, pls. 1-2.

Richardson, J.B., Streel, M., Hassan, A. \& Steemans, Ph. 1982. A new spore assemblage to correlate between the Breconian (British Isles) and the Gedinnian (Beligium). Ann. Soc. Géol. Belg., 105, 135-143, pl. 1.

\section{Explanation of Plate 3}

All figures are $\times 2,000$, except where otherwise stated, and were photographed using Nomarski differential interference contrast.

Fig. 1 Ambitisporites sp. B Richardson \& Ioannides, 1973; Myreton 8A \& B/1, 231 1117, FM 77.

Fig. 2. Aneurospora sp. B; Myreton 8 A \& B/2, 136 1122, FM 88.

Figs. 3, 4. Granulatasporites sp. B; Myreton, slide 8A \& B/2, 080 0999; showing coarse grana, FM 78.

Figs. 5, 6. Synorisporites cf. verrucatus Richardson and Lister, 1969; Myreton 8A \& B/2, 112 1112: fig. 5, proximal view; fig. 6, showing distal verrucae, FM 79.

Fig. 7. ?Synorisporites sp. D; Wormit 6A, 072 0966, FM 80.

Fig. 8. Apiculiretusispora sp. E; Myreton 8A \& B/2, 200 1066, FM 81.

Figs. 9, 10. ?Dibolisporites sp. A; Monikie Burn, J031 A/180, 091 0956, at different levels of focus, FM 82, $\times 1,000$. 

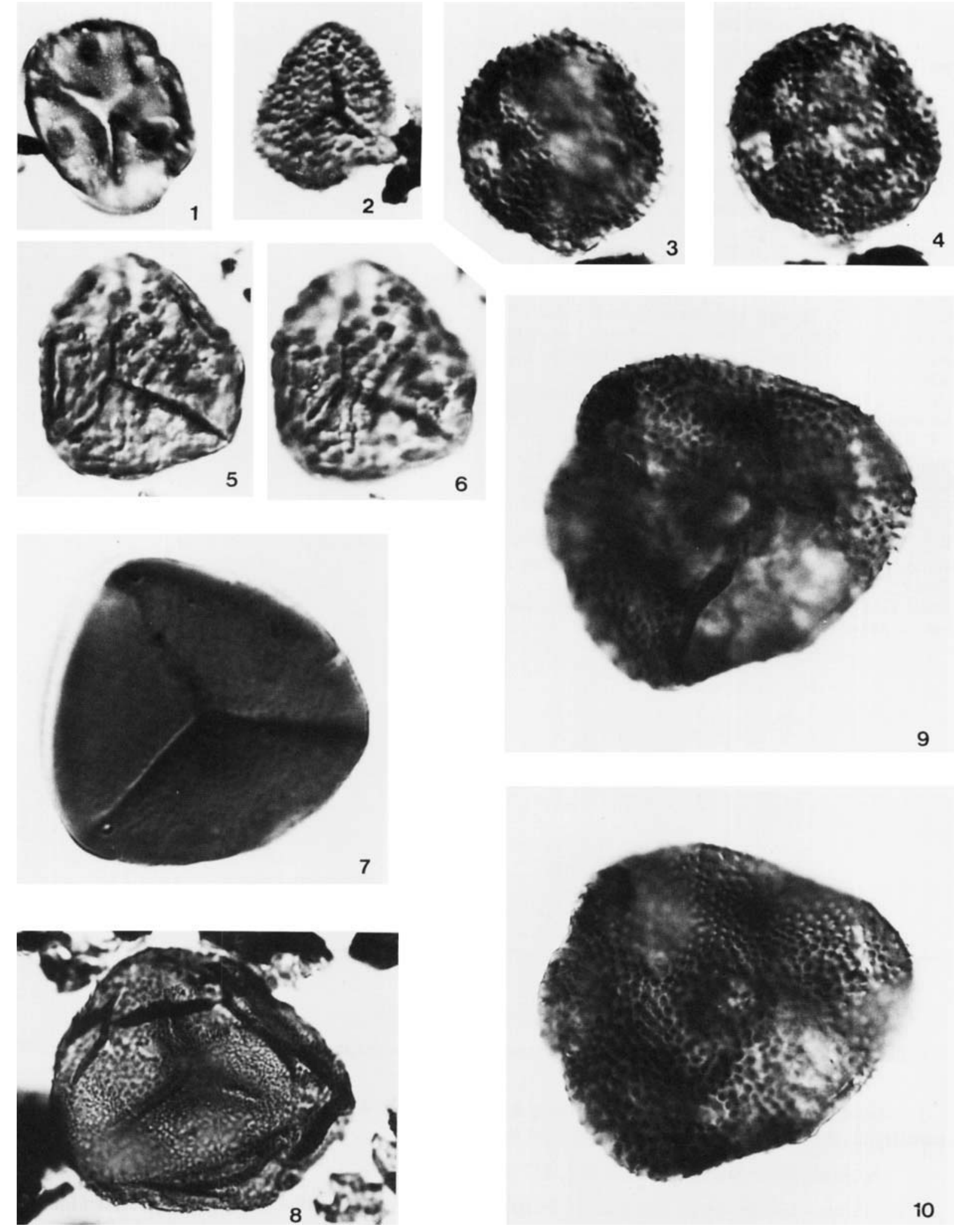
Shepeleva, E. D. 1963. Spores from the Lower Devonian beds of the Podolian Dniester River area (in Russian). Data on Regional Stratigraphy of USSR, Moscow, 98-101.

Steemans, $\mathrm{Ph}$. 1981. Etude stratigraphique des spores dans les couches de transition "Gedinnien-Siegenien" à Nonceveux et à Spa (Belgique). Ann. Soc. Géol. Belg., 104, 41-59, pls. $1-3$.

Steemans, Ph. 1982. L'age du poudingue de Fepin (base du Gedinnien) à Lahonry (Belgique). Bull. Soc. Belg. Géol., 90, 331-340.

Streel, M., Fairon-Demaret, M., Otazo-Bozo, N. \& Steemans, Ph. 1981. Etudes stratigraphiques des spores du Dévonien inférieur au bord sud du synclinorium de Dinant (Belgique) et leurs applications. Ann. Soc. Géol. Belg., 104, 173-191.

Strother, P. \& Traverse, A. 1979. Plant microfossils from Llandoverian and Wenlockian rocks of Pennsylvania. Palynology, 3, 1-22.

Thirlwall, M.F. 1983. Isotope geochemistry and origin of calcalkaline lavas from a Caledonian continental margin volcanic arc. Jour. Volcanology Geothermal Research, 18, 589-631.

Turner, S. 1973. Siluro-Devonian thelodonts from the Welsh Borderlands. Jour. Geol. Soc., 129, 557-584.

Westoll, T. S. 1945. A new cephalaspid fish from the Downtonian of Scotland. Trans. R. Soc. Edinburgh, 61, 341-357.

Westoll, T.S. 1977. Northern Britain. In House et al., A correlation of Devonian rocks of the British Isles. Geol. Soc. Lond., Special Report 8, 110 pp.

White, E. I. 1950. The vertebrate faunas of the Lower Old Red Sandstone of the Welsh Borders. Bull.Br. Mus. Nat. Hist, A 1, 57-67.

Whitehead, T. H. \& Pocock, R. W. 1947. Dudley and Bridgnorth. Mem. Geol. Surv. Gt. Br.

\section{Explanation of Plate 4}

All figures are $\times 2,00(0$, except where otherwise stated, and were photographed using Nomarski differential interference contrast.

Figs. 1, 2. Synorisporites cf. verrucatus Richardson \& Lister, 1969; West Craig 6/2/93, 069 1024: fig. 1, proximal focus; fig. 2, distal focus showing verrucae and muri, FM 83.

Fig. 3. ?Cymbosporites sp.; Slatefield, 24/7/483, 1120894 , FM 84.

Figs. 4, 5. Cymbosporites dittonensis Richardson \& Lister, 1969; Wormit 6A, (064 (1999: fig. 4, proximal focus showing thin membrane over contact area and tetrad mark; fig. 5, distal view showing sculpture, FM 85.

Figs. 6, 7. ?Samarisporites sp. A; West Craig, 6/2/93, 1460812 , at different levels of focus, FM 86, $\times 1,0(00$. 

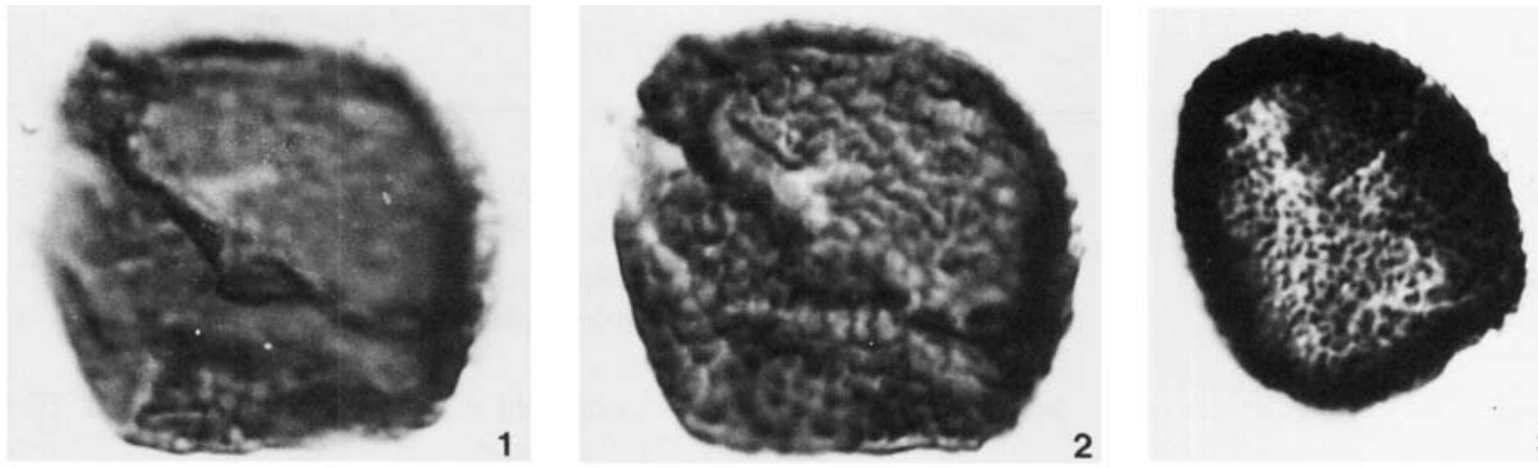

3
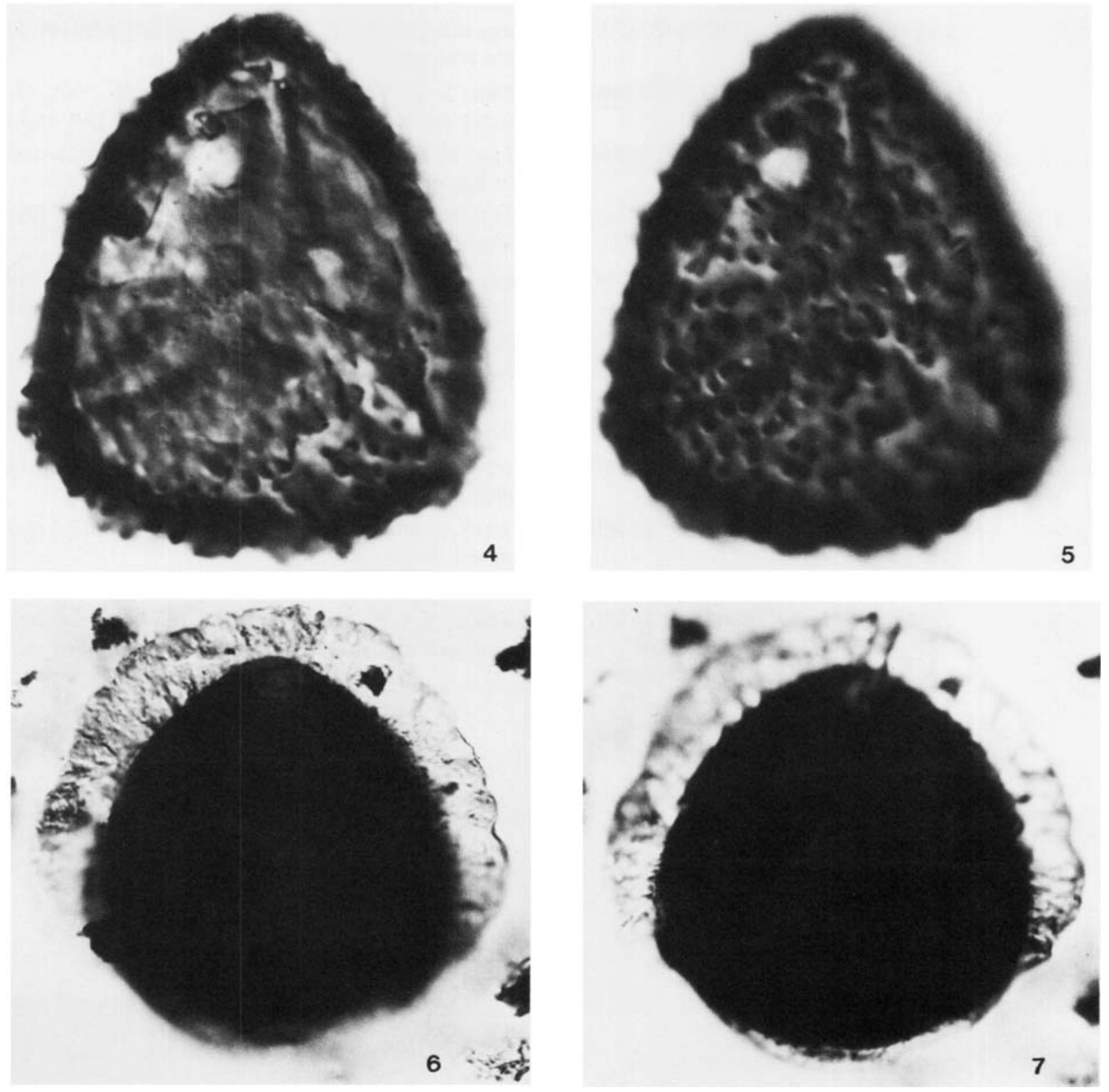


Locality Sample No. $\quad \begin{gathered}\text { National Grid } \\ \text { Reference }\end{gathered}$ Location

\begin{tabular}{|c|c|c|c|}
\hline \multicolumn{4}{|l|}{ Angus } \\
\hline Balgavies & $\begin{array}{l}\text { MV9 } \\
\text { J } 11 \mathrm{~A}-\mathrm{C}\end{array}$ & NO/53855186 & $\begin{array}{l}\text { C. } 500 \mathrm{~m} . \mathrm{N} . \mathrm{N} . \text { W. of Balgavies House quarry on south side } \\
\text { of B } 9114 \text { E. of Westerton cross roads. } 2 \mathrm{~m} \text { of sst exposed. }\end{array}$ \\
\hline Balmashanner & $\begin{array}{l}\text { MV12-18 } \\
\text { J17G-J }\end{array}$ & $\mathrm{NO} / 45864922$ & $\begin{array}{l}\text { S. side of Balmashanner Hill, disused quarries, N. quarry } \\
\text { face } 7 \mathrm{~m} \text { grey sandstones and siltstones, just north of old } \\
\text { building. }\end{array}$ \\
\hline Craiksfold & $12 / 1-4$ & $\mathrm{NO} / 52795571$ & $\begin{array}{l}\text { S.W. of Craiksfold, } 8.1 \mathrm{~km} \mathrm{N.E.} \mathrm{of} \mathrm{Forfar,} \mathrm{S.} \mathrm{of} \mathrm{Tillywhand-} \\
\text { land. Disused quarry, at westernmost end } 12 \mathrm{~m} \text { of shales } \\
\text { and sandstones exposed. }\end{array}$ \\
\hline Leysmill & MV6 & $\mathrm{NO} / 60204772$ & $\begin{array}{l}\text { 1) Large disused quarry } 300 \mathrm{~m} \mathrm{~N} \text {.W. of Leysmill, sst conglom- } \\
\text { erate and tuffs. }\end{array}$ \\
\hline & $\mathrm{J} 25$ & $\mathrm{NO} / 59724842$ & $\begin{array}{l}\text { 2) } 1.6 \mathrm{~km} \mathrm{~S} \text {. of Friockheim, quarry on } \mathrm{W} \text {. side of disused } \\
\text { railway track, conglomerate, sandstone, tuff and shale. }\end{array}$ \\
\hline Monikie Burn & J31 A-E & $\mathrm{NO} / 54753750$ & $\begin{array}{l}3.2 \mathrm{~km} \mathrm{~N} . \mathrm{W} \text {. of Carnoustie, N. bank } 30 \mathrm{~m} \text { upstream from } \\
\text { foot bridge, } 2 \mathrm{~m} \text { of grey shale. }\end{array}$ \\
\hline Murroes Manse & $\begin{array}{l}\text { J28 A-E } \\
20 / 2-3\end{array}$ & $\mathrm{NO} / 46223520$ & $\begin{array}{l}7.2 \mathrm{~km} \mathrm{~N} \text {.E. of Dundee on E. bank of Murroes Burn c. } 3 \mathrm{~m} \\
\text { of shales exposed. }\end{array}$ \\
\hline $\begin{array}{l}\text { Myreton } \\
\text { (Westall Terrace) }\end{array}$ & $\begin{array}{l}8 \text { A \& B } \\
\text { MV } 6\end{array}$ & $\mathrm{NO} / 44203700$ & $\begin{array}{l}\text { Large disused quarries } S \text {. of Myreton, silty sandstone band } \\
\text { in } 4 \mathrm{~m} \text { of sandstone and conglomerate plants and miospores. }\end{array}$ \\
\hline Slatefield & $\begin{array}{l}\text { J17 A-E } \\
24 / 3,4,7\end{array}$ & $\mathrm{NO} / 45364913$ & $\begin{array}{l}\text { Quarry } 1.6 \mathrm{~km} \mathrm{~S} \text {. of Forfar } 90 \mathrm{~m} \text { along track on E. side of } \\
\text { A } 925 \text {, collected from alternating sandstones and siltstones. }\end{array}$ \\
\hline $\begin{array}{l}\text { Tillywhandland } \\
\text { (Turin Hill) }\end{array}$ & $\begin{array}{l}\text { MV7 } \\
\text { J14 A,B }\end{array}$ & $\mathrm{NO} / 51895371$ & $\begin{array}{l}\text { E. end of disused quarry, series of alternating shales, sand- } \\
\text { stones and conglomerate in quarry face. }\end{array}$ \\
\hline West Craig & $\mathrm{J} 18 \mathrm{~B}$ & NO/45534849 & $\begin{array}{l}\text { Second quarry E. of A } 929 \text {, just S. of track, } 3.5 \mathrm{~m} \text { of sand- } \\
\text { stones and shales in disused quarry face. }\end{array}$ \\
\hline Whitehouse Den & $\mathrm{J} 20 \mathrm{~A}$ & NO/42563989 & $\begin{array}{l}\text { E. bank of small stream } 9.7 \mathrm{~km} \mathrm{~S} \text {. of Forfar; } 2.5 \mathrm{~m} \text { of shales } \\
\text { exposed in stream bank. }\end{array}$ \\
\hline
\end{tabular}

Fife

Wormit Bay J35A-D NO/38632576

S. end of Tay Bridge $20 \mathrm{~m}$ west from wall of fishing lodge. Shales and sandstone in foreshore and upper beach.

Wormit Bay $\quad 1-12$

Collected by Dr. M. F. Thirlwall. 